\title{
KAJIAN MODALITAS LINGUISTIK FUNGSIONAL SISTEMIK PADA TEKS DEBAT CAPRES-CAWAPRES PADA PILPRES 2014-2019 DAN RELEVANSINYA DENGAN PEMBELAJARAN WACANA DI SEKOLAH
}

\author{
Abdul Azis Faradi \\ Universitas Mataram \\ abdulaziz.faradi@yahoo.com
}

\begin{abstract}
Abstrak
Penelitian ini mengkaji tentang teks debat kandidat Capres-Cawapres Pilpres Republik Indonesia pada 2014-2019 dengan menggunakan teori Linguistik Fungsional Sistemik (LFS) yang direlevansikan dengan pembelajaran wacana di sekolah. Penelitian ini berkaitan dengan tiga metafungsi bahasa yaitu pemaparan, pertukaran dan perangkai pengalaman. Penelitian ini difokuskan pada fungsi pertukaran yang direalisasikan dalam sistem nilai modalitas dan pesan nilai dalam konteks ideologi, budaya, dan situasi yang terdapat dan mendominasi pada teks debat kandidat Capres-Cawapres Pilpres 2014-2019. Setelah data dikumpulkan, kemudian akan mendeskripsikan pesan nilai-nilai dibalik frekuensi yang dominan pada modalitas yang direalisasikan dengan konteks ideologi, konteks budaya dan konteks situasi. Hasil penelitian ini menunjukkan bahwa modalitas yang ditemukan dalam teks debat pasangan JW - JK (Joko Widodo - Jusuf Kalla) lebih besar daripada pasangan PS - HR (Prabowo Subianto - Hatta Rajasa). Ini berdasarkan analisis modalitas teks. Hasil kajian ini dapat direlevansikan dengan pembelajaran wacana di sekolah dalam hal menganalisis wacana atau teks dengan menggunakan teori LFS.
\end{abstract}

Kata Kunci: Teks, Modalitas dalam LFS, dan Pembelajaran Wacana

\begin{abstract}
This research studies the texts of debate of President and Vice President candidate of Republic of Indonesia in 2014-2019 period by using the theory of Systemic Functional Linguistics (SFL) which is related with discourse analysis subject learning at school. This research deals with three metafunctions of languages such as: exposure, exchange and experience relation. This research is focused on the function realized in the exchange rate system and the modalities of the value message in the context of ideology, culture, and situations that found and dominates in the debate's texts of President and Vice President candidate of Republic of Indonesia in 2014-2019 period. After collecting the data, then describing the values behind the dominant frequency in the modalities that realized in the context of ideology, cultural context and the context of the situation. The result of data analysis shows that modality found in the debate text of JW-JK is more than PS-HR. This is based on the text modality analysis. The result of this research can be related to discourse subject learning in school in terms of analyzing discourse or text by using SFL theory.
\end{abstract}

Keywords: Text, Modality in SFL, and Learning Modalities Discourse

\section{PENDAHULUAN}

Bahasa sebagai salah satu media komunikasi yang dilakukan secara lisan dan tulisan dapat diimplementasikan dalam berbagai pengungkap pikiran, perasaan antar satu dengan yang lain dalam interaksi sosial. Oleh karena itu, bahasa menjadi suatu hal yang sangat esensial dalam mengungkap suatu realitas antara teks yang ada dengan konteks komunikasi baik secara lisan dan tulisan dalam kegiatan pidato, diskusi, maupun debat kandidat, dan 
komunikasi secara tertulis dalam bentuk hasil teks naskah debat kandidat dan teks pidato baik resmi dan tidak resmi. Dari sisi fungsional, bahasa memiliki metafungsi yaitu fungsi pemaparan, pertukaran dan perangkai pengalaman atau pengorganisasian. Pemakaian fungsi bahasa dalam konteks debat dapat diimplementasikan dalam debat kandidat Capres-Cawapres Pilpres 2014-2019 sebagai salah satu metafungsi bahasa yaitu fungsi pertukaran gagasan, pikiran dan pandangan dalam sistem demokrasi terbuka.

Peran strategis bahasa sebagai media komunikasi lisan dalam debat kandidat visi misi Capres-Cawapres Republik Indonesia pada pemilu 2014-2019 dapat dilakukan sebagai implementasi dalam melaksanakan proses pesta demokrasi secara transparan dan akuntabel dalam konsep pertukaran suatu visi misi dalam debat kandidat Capres-Cawapres yang dapat diakses oleh seluruh rakyat Indonesia secara terbuka melalui media massa dan media elektronik lainnya.

Teks visi misi debat kandidat CapresCawapres Republik Indonesia merupakan suatu teks yang sangat menarik untuk dianalisis dengan menggunakan teori Linguistik Fungsional Sistemik selanjutnya disingkat (LFS). Teori LFS atau pendekatan sistemik dijadikan sebagai kerangka berpikir dan interpretasi di dalam memandang bahasa sebagai metafungsi pertukaran yang strategis sesuai konteks situasi. Selanjutnya teori LFS berpandangan bahwa bahasa dapat memerankan tiga metafungsi, yakni fungsi pemapran (ideational function), fungsi pertukaran (interpersonal function), dan perangkai pengalaman (textual function).

Pada substansi dalam perspektif LFS, bahasa sebagai suatu sistem arti dan sistem bentuk dan ekspresi untuk dapat merealisasikan arti tersebut. Ada dua konsep yang mendasar teori LFS adalah: pertama, bahasa merupakan fenomena sosial yang berwujud sebagai semiotik sosial dan kedua, bahasa merupakan teks yang konstrual dan merujuk pada konteks sosial.

Penganalisisan wacana berarti penganalisisan bahasa dalam pemakaiannya. Analisis wacana (discourse analysis) adalah ilmu yang dikembangkan untuk menganalisis suatu unit semantik berupa novel, percakapan, cerita pendek, puisi, esai, dan paragraf. Kajian wacana adalah sesuatu kajian yang mengarahkan kita kepada pemahaman tentang bahasa. Hubungan bahasa atau teks dengan konteks sosial menentukan dan ditentukan oleh teks. Dengan kalimat lain, dalam suatu konteks sosial tertentu hanya konteks sosial tertentu pula yang dapat dirujuk dalam 
komunikasi baik lisan dan tulisan.

\section{KONSEP DAN KERANGKA TEORI KONSEP TEKS (TEXT)}

Teks adalah bahasa yang sedang melaksanakan tugas tertentu dalam konteks situasi (Halliday \& Hasan, 1992: 13). Teks berarti rangkaian kata, klausa, atau kalimat yang saling berhubungan dan membentuk suatu makna. Teks sebagai isi linguistik dari tuturan-tuturan; arti semantik tetapnya pada kata-kata, ekspresi dan kalimat, tetapi bukan inferensi (pemahamannya) yang tersedia pada mitra tutur yang bergantung pada konteks di mana kata-kata, ekspresi dan kalimat itu digunakan. Dalam kajian ini, teks dikonsepkan sebagai bahasa yang diberdayakan dalam proses komunikasi, lebih utamanya dalam konteks debat kandidat Capres-Cawapres (bandingkan, Schiffrin, 2007: 571).

\section{Konsep Debat (Debate)}

Debat bermakna pembahasan, diskusi, perbantahan, silat lidah, pendebatan (Kamus Umum Bahasa Indonesia, 2012: 174). Debat yang dimaksudkan dalam tulisan ini dapat diuraikan sebagai suatu kegiatan bertukar pikiran, gagasan dan argumentasi yang kuat dengan mempertahankan pertukaran visi-misi yang diperdebatkan baik jangka pendek maupun jangka panjang dari masing-masing kandidat berdasarkan konsep dan pandangan, sikap dan pertimbangan pribadi antara kedua pasangan Capres-Cawapres pada penjabaran program kerja dalam kegiatan debat kandidat secara terbuka pada Pilpres 2014-2019. Debat, secara lebih khusus tidak lain adalah fungsi bahasa yang dalam istilah teknis LFS adalah fungsi antarpersonal. (bandingkan Halliday, 1994:vii).

\section{Konsep Linguistik Fungsional Sistemik (LFS)}

Persepektif LFS bahasa adalah sistem arti dan sistem lain (sistem bentuk dan ekspresi) untuk merealisasikan arti tersebut. Teori ini memiliki dua konsep dasar yaitu: a) bahasa merupakan fenomena sosial yang terwujud sebagai semiotik sosial dan b) bahasa merupakan teks yang konstrual (saling menentukan dan merujuk) dengan konteks sosial. Dalam kaitannya dengan kajian ini, LFS lebih ditekankan lagi dalam hal kefungsionalan bahasa sesuai dengan kebutuhan pemakainya.

\section{Konsep Nilai (Concept of Value)}

Nilai (value) yang dimaksudkan dalam kajian ini adalah segala sesuatu yang memberi manfaat dalam kehidupan manusia yang ditemukan berdasarkan penggunaan morfem, kata, frase (group), dan klausa. Nilai mencakup yaitu: 1) 
sesuatu yang berharga, keyakinan yang dipegang sedemikian rupa oleh seseorang sesuai dengan tututan hati nuraninya. 2) Seperangkat keyakinan dan sikap-sikap pribadi seseorang tentang kebenaran, keindahan, dan penghargaan dari suatu pemikiran, objek atau perilaku yang berorientasi pada tindakan dan pemberian arah serta makna pada kehidupan seseorang. (bandingkan Kluckhohn via Abidin dan Soebani, 2012: 37; Suherman, 2012:48 menyebutnya attendant ideologi).

\section{TEORI LINGUISTIK FUNGSIONAL SISTEMIK (LFS)}

LFS mendasarkan kajiannya pada dua pendekatan, yakni pertama memiliki pengertian bahwa pemakaian bahasa merupakan sistem semiotik. Sebagai semiotik, bahasa terjadi dari dua unsur, yakni arti dan ekspresi. Hubungan kedua unsur ini adalah hubungan realisasi, yakni arti direalisasikan atau dikodekan oleh ekspresi. Konsep kedua mengandung pengertian bahwa LFS berfokus pada kajian teks atau wacana dalam konteks sosial, teks dibatasi sebagai unit bahasa yang fungsional dalam konteks sosial (Halliday, 1994 via Saragih: 5). Bahasa yang fungsional memberi arti kepada pemakai bahasa. Dengan demikian, teks adalah unit arti atau unit semantik bukan unit tata bahasa (grammatical unit), seperti kata frase, klausa, paragraf, dan naskah. Sebagai unit arti, teks dapat direalisasikan oleh berbagai unit tata bahasa. Hal ini berarti teks dapat berupa suatu naskah (buku), paragraf, klausa kompleks, klausa, frase, grup atau bunyi. Jika, satu unit bahasa mempunyai arti dalam konteks sosial, unit bahasa itu disebut teks. Berdasarkan teori LFS konteks mencakup dua pengertian, yakni 1) konteks linguistik (yang disebut konteks internal); 2) konteks sosial (konteks eksternal).

Konteks yang dekat kepada teks disebut lebih konkrit atau nyata dan konteks yang lebih jauh dari teks disebut abstrak (Halliday, 1994 dikutip kembali oleh Saragih, 2006: 193).

\section{Teori Modalitas (Modality) dan Nilai Modalitas (Value Of Modality)}

Berdasarkan jenisnya, Halliday (1994: 89) menyatakan bahwa ada dua jenis modalitas secara garis besar yaitu modalization dan modulation. Modalization direalisasikan oleh: i) probability: 'possibly, probably dan certainly' dan ii) usuality: 'sometimes, usually dan always' sedangkan modulation direalisasikan oleh (i) obligation: 'allowed to, supposed to, required to' dan (ii) inclination: willing to, anxious to dan determined to'.

Halliday (1994: 357) menyatakan "the third variable in modality is the value 
that is set on the modal judgement: high, median, or low”. Nilai modalitas sebagai variabel utama yang mendominasi pada teks debat kandidat Capres-Cawapres dengan modalitas tinggi, sedang dan rendah.

Sejalan dengan itu, Mathiessan (1992: 428) yang menyatakan, "there are three values on this scale. Two of these are other; 'high' and 'low' and one is in between median”. Maksudnya ada tiga jenis nilai yaitu tinggi, menengah dan rendah. Berdasarkan pendapat di atas maka dapat disimpulkan bahwa ada tiga tingkat frekuensi nilai modalitas yaitu tinggi, menengah dan rendah.

\section{Teori Orientasi Modalitas (Modality Orientation)}

Halliday (1994:357) menyatakan bahwa, "orientation: that is, the distinction between, subjective and objective modality, and between the explicit and implicit variants." Saragih (2001: 83) menyatakan dari segi orientasinya, modalitas dapat bersifat subjektif atau objektif. Dengan kriteria orentasi teersebut, modalitas juga dapat eksplisit atau implisit.

Modalitas subjektif menunjukan bahwa pendapat atau pertimbangan pribadi terhadap pengalaman yang disampaikan dilakukan oleh pemakai bahasa yang langsung terlibat dalam intraksi atau intraktan seperti pada klausa pasangan Capres-Cawapres PS-HR berkata: [67] "Kami sadar sepenuhnya setiap usaha perbaikan *pasti ada halangan, tumpang tindih peraturan, pemimpin politik yang berasal dari latar belakang dengan kepentingan berbeda." Selanjutnya Matthiessan (1992: 427) menyatakan bahwa modalitas dapat diungkapkan dengan dua cara yaitu orientasi dan manifestasi. Orentasi teerdiri atas subjektif dan objektif sedangkan manifestasi terdiri atas implisit dan eksplisit.

\section{PEMBAHASAN}

\section{IDENTIFIKASI JUMLAH DAN JENIS MODALITAS}

Analisis modalitas pada teks debat tersebut dilakukan dengan cara menjaring modalitas yang terdapat dalam teks, baik modalitas dalam bentuk modalisasi (pasti, percaya, tentu, menegaskan, yakin, akan, bertekad, mungkin, insya Allah, barangkali, terus menerus, selalu, sering, biasa, semakin, kadang-kadang) maupun modalitas dalam bentuk modulasi (harus, wajib, perlu, mesti, mampu, bisa, diharapkan, boleh, dapat, mau, ingin). Analisis kedua jenis modalitas ini tidak diklasifikasi, melainkan dianalisis sebagai bentuk yang sama, karena perhatian utama adalah makna, yang digolongkan berdasarkan jenis modalitas dan nilai yang 
dikandungnya (tinggi, menengah, rendah). Hal ini menunjukkan bahwa jenis modalitas yang paling dominan digunakan adalah jenis modalitas modulasi (modulation) yang menggunakan pengungkap atau realisasi modalitas sebesar 428 atau 76,16\% dibanding jenis modalitas modalisasi (modalization) yang menggunakan pengungkap atau realisasi modalitas sebesar 134 atau 23,84\%.

Adapun frekuensi menunjukkan bahwa pada teks debat pertama menggunakan pengungkap atau realisasi modalitas yang paling rendah yaitu sebesar 77 atau 13,71\%. Teks debat kedua menggunakan pengungkap modalitas sebanyak 103 atau 18,33\%. Teks debat ketiga menggunakan pengungkap modalitas yang paling dominan yaitu sebesar 149 atau 26,51\%. Teks debat keempat menggunakan pengungkap modalitas sebanyak 106 atau 18,86\% dan teks debat kelima menggunakan pengungkap modalitas sebesar 127 atau $22,59 \%$.

Penggunaan pengungkap atau realisasi modalitas yang paling dominan yang digunakan pada kelima teks debat tersebut adalah pengungkap atau realisasi modalitas *harus, *wajib, *perlu, *mesti yang termasuk ke dalam modalitas modulasi keharusan tinggi yaitu sebesar 218 atau $38,79 \%$ dibanding dengan pengungkap atau realisasi modalitas lainnya. Pengungkap modalitas atau realisasi modalitas yang paling rendah jumlah kemunculannya yaitu ^makin yang masuk dalam kategori modalitas modalisasi keseringan menengah dan "kadang-kadang yang termasuk modalitas modalisasi keseringan rendah dengan masingmasingnya sebesar 1 atau $0,18 \%$. Pengungkap modalitas atau realisasi modalitas seperti ${ }^{\#}$ barangkali sebagai modalitas kemungkinan rendah dan *ditetapkan sebagai bentuk modalitas kecenderungan tinggi tidak ditemukan sama sekali dalam kelima teks debat tersebut.

\section{FREKUENSI KEMUNCULAN MODALITAS}

Sesuai dengan pembahasan permasalahan penelitian, ditemukan bahwa teks debat Capres-Cawapres dari yang pertama hingga kelima terdiri atas 563 klausa untuk pasangan PS-HR dan 587 klausa untuk pasangan JW-JK. Untuk mengetahui rincian frekuensi kemunculan modalitas kelima teks debat tersebut dapat dilihat pada tabel berikut ini. 
RETORIKA: Jurnal Ilmu Bahasa, Vol. 1, No.2 Oktober 2015, 239

\begin{tabular}{|c|c|c|c|c|c|}
\hline $\begin{array}{c}\text { Teks } \\
\text { Debat ke- }\end{array}$ & $\begin{array}{c}\text { Nama Pasangan } \\
\text { Calon }\end{array}$ & No. Klausa & $\begin{array}{l}\text { Jumlah } \\
\text { Klausa } \\
\end{array}$ & $\begin{array}{c}\text { Jumlah } \\
\text { Modalitas } \\
\end{array}$ & $\begin{array}{c}\text { Persentase } \\
(\%)\end{array}$ \\
\hline \multirow{2}{*}{ 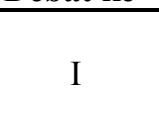 } & $\overline{\mathrm{PS}-\mathrm{HR}}$ & {$[1]-[95]$} & 95 & 41 & 43,15 \\
\hline & $\mathrm{JW}-\mathrm{JK}$ & {$[1]-[92]$} & 92 & 36 & 39,13 \\
\hline \multirow{2}{*}{ II } & $\mathrm{PS}-\mathrm{HR}$ & {$[96]-[193]$} & 98 & 43 & 43,88 \\
\hline & $\mathrm{JW}-\mathrm{JK}$ & {$[93]-[190]$} & 98 & 60 & 61,22 \\
\hline \multirow{2}{*}{ III } & $\mathrm{PS}-\mathrm{HR}$ & {$[194]-[314]$} & 121 & 64 & 52,90 \\
\hline & $\mathrm{JW}-\mathrm{JK}$ & {$[191]-[323]$} & 133 & 85 & 63,91 \\
\hline \multirow{2}{*}{ IV } & $\mathrm{PS}-\mathrm{HR}$ & {$[315]-[425]$} & 111 & 57 & 51,35 \\
\hline & $\overline{J W}-\mathrm{JK}$ & {$[324]-[439]$} & 116 & 49 & 42,24 \\
\hline \multirow{2}{*}{ V } & $\mathrm{PS}-\mathrm{HR}$ & {$[426]-[563]$} & 138 & 56 & 40,58 \\
\hline & $\overline{J W-J K}$ & {$[440]-[587]$} & 148 & 71 & 47,97 \\
\hline \multicolumn{2}{|r|}{ Total } & & 1150 & 562 & - \\
\hline
\end{tabular}

Tabel 01

Rincian Frekuensi Kemunculan Modalitas Teks Debat untuk masing-masing CapresCawapres

Pada tabel 01 di atas menunjukkan bahwa frekuensi kemunculan modalitas yang paling tinggi untuk pasangan Prabowo - Hatta terdapat pada teks debat ke (III) yaitu sebesar 52,90\% (jumlah modalitas : jumlah klausa x 100\% atau 41 : $95 \times 100 \%)$. Berikutnya pada teks debat ke (IV) yaitu sebesar 51,35\%. Kemudian diikuti oleh teks debat ke (II) yaitu sebesar
$43,88 \%$. Selanjutnya pada teks debat ke (I) yaitu sebesar $43,15 \%$ dan frekuensi kemunculan modalitas yang paling rendah terdapat pada teks debat ke (V) yaitu sebesar $40,58 \%$.

Persentase kemunculan modalitas untuk pasangan PS-HR pada kelima debat tersebut dapat digambarkan seperti chart bar berikut ini.

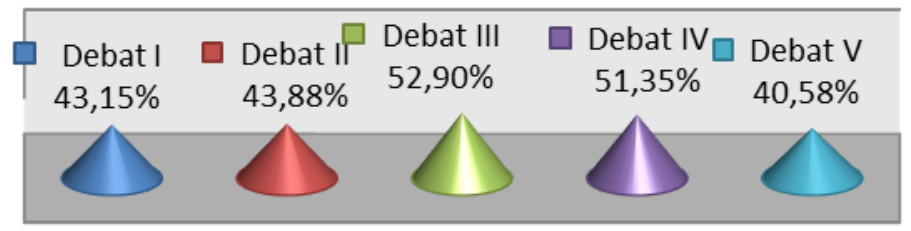

Chart Bar 1

Persentase Frekuensi Kemunculan Modalitas Pasangan PS - HR Pada Kelima Debat

Frekuensi kemunculan modalitas untuk pasangan JW-JK pada tabel 01 di atas menunjukkan bahwa frekuensi keseringan kemunculan modalitas yang paling tinggi untuk terdapat pada teks debat ke (III) yaitu sebesar $63,91 \%$ (jumlah modalitas: jumlah klausa $\times 100 \%$ atau 85: $133 \times 100 \%$ ). Berikutnya pada teks debat ke (II) yaitu 
sebesar $61,22 \%$. Kemudian diikuti oleh teks debat ke (V) yaitu sebesar $47,97 \%$. Selanjutnya pada teks debat ke (IV) yaitu sebesar 42,24\% dan Frekuensi kemunculan modalitas yang paling rendah terdapat pada

Persentase kemunculan modalitas untuk pasangan JW - JK pada kelima debat tersebut dapat digambarkan seperti chart bar berikut ini. teks debat ke (I) yaitu sebesar 39,13\%.

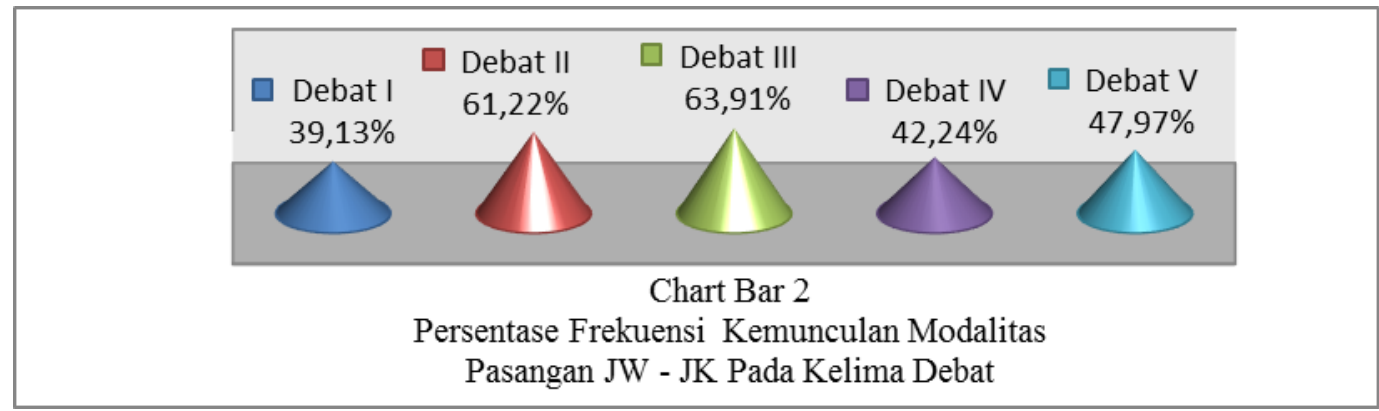

Berdasarkan data rincian frekuensi persentase frekuensi kemunculan modalitas kemunculan modalitas untuk kedua dari keseluruhan sesi debat untuk pasangan pasangan Capres-Cawapres tersebut PS - HR dari debat yang pertama hingga sebagaimana tersaji pada tabel 02 di atas, kelima yaitu dengan rumus sebagai berikut: maka dapatlah diakumulasikan bahwa

$\frac{\text { jumlah total modalitas }}{\text { jumlah total klaus } 2 .} \times 100 \%$

$\frac{41+43+64+57+56}{95+98+121+111+138} \times 100 \%=\frac{261}{563} \times 100 \%=46,36 \%$

Persentase Frekuensi keseringan kemunculan modalitas untuk pasangan JW-JK dari debat pertama hingga kelima yaitu sebesar:

$\frac{36+60+85+49+71}{92+98+133+116+148} \times 100 \%=\frac{301}{587} \times 100 \%=51,28 \%$

Lebih jelasnya, komparasi persentase frekuensi kemunculan modalitas dari keseluruhan sesi debat untuk kedua pasangan Capres-Cawapres tersebut dapat dilihat pada chart bar berikut ini.

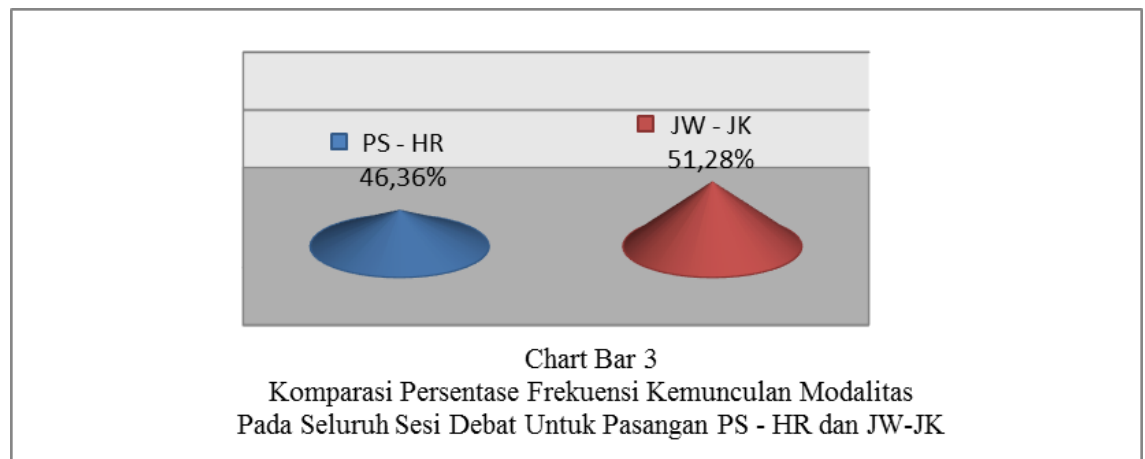




\section{JENIS MODALITAS TEKS DEBAT}

\section{PERTAMA}

Berdasarkan teks debat pertama menunjukkan bahwa jenis modalitas teks debat pertama yang paling dominan digunakan adalah jenis modalitas modulasi (modulation) yang menggunakan pengungkap atau realisasi modalitas sebesar 56 atau 72,73\% dibanding jenis modalitas modalisasi (modalization) yang menggunakan pengungkap atau realisasi modalitas sebesar 21 atau 27,27\%.

Adapun teks debat pertama menunjukkan bahwa teks debat pertama menggunakan pengungkap atau realisasi modalitas *harus, *wajib, *perlu, *mesti yang merupakan bagian dari modalitas modulasi keharusan tinggi sebagai pengungkap atau realisasi modalitas yang paling dominan yaitu sebesar 39 atau $50,65 \%$ dibanding pengungkap modalitas lainnya. Pengungkap atau realisasi modalitas ${ }^{\#}$ barangkali, ^makin, ${ }^{\#}$ kadangkadang, 'mampu, *ditetapkan, ^mau tidak ditemukan sama sekali pada teks tersebut.

Secara terperinci, tabel di atas dapat dijelaskan bahwa jenis modalitas modalisasi untuk pasangan PS-HR sebesar 9 atau $11,69 \%$ dengan pengungkap atau realisasi modalitas ^akan, ^bertekad, 'mungkin, insya Allah sebagai bagian dari modalitas modalisasi kemungkinan menengah yang paling dominan sebesar 7 atau $9,09 \%$. Jenis modalitas modulasinya sebesar 32 atau 41,56\% dengan pengungkap atau realisasi modalitas *harus, *wajib, *perlu, *mesti sebagai bagian dari modalitas modulasi keharusan tinggi yang paling dominan yaitu sebesar 21 atau $27,27 \%$.

Untuk pasangan JW-JK dapat dijelaskan secara terperinci bahwa jenis modalitas modalisasinya sebesar 12 atau $15,58 \%$ dengan pengungkap atau realisasi modalitas ^akan, ^bertekad, ^mungkin, insya Allah sebagai bagian dari modalitas modalisasi kemungkinan menengah yang paling dominan sebesar 10 atau 12,99\%. Jenis modalitas modulasinya sebesar 24 atau $31,17 \%$ dengan pengungkap atau realisasi modalitas *harus, *wajib, *perlu, *mesti sebagai bagian dari modalitas modulasi keharusan tinggi yang paling dominan yaitu sebesar 18 atau $23,38 \%$.

\section{JENIS MODALITAS TEKS DEBAT KEDUA}

Berdasarkan teks debat kedua menunjukkan bahwa jenis modalitas teks debat kedua yang paling dominan digunakan adalah jenis modalitas modulasi (modulation) yang menggunakan pengungkap atau realisasi modalitas sebesar 78 atau $75,73 \%$ dibanding jenis modalitas modalisasi (modalization) yang 
menggunakan pengungkap atau realisasi modalitas sebesar 25 atau 24,27\%. Adapun data tersebut menunjukkan bahwa teks debat kedua menggunakan pengungkap atau realisasi modalitas " bisa, " \#dapat yang merupakan bagian dari modalitas modulasi keharusan rendah sebagai pengungkap atau realisasi modalitas yang paling dominan yaitu sebesar 36 atau $34,95 \%$ dibanding pengungkap modalitas lainnya. Pengungkap atau realisasi modalitas \#barangkali, 'makin, 'mampu, *ditetapkan tidak ditemukan sama sekali pada teks tersebut.

Secara terperinci dari tabel di atas dapat dijelaskan bahwa jenis modalitas modalisasi untuk pasangan PS-HR sebesar 11 atau 10,68\% dengan pengungkap atau realisasi modalitas ^akan, ^bertekad, 'mungkin, insya Allah sebagai bagian dari modalitas modalisasi kemungkinan menengah yang paling dominan sebesar 10 atau 9,71\%. Jenis modalitas modulasinya sebesar 22 atau $21,36 \%$ dengan pengungkap atau realisasi modalitas "bisa, ${ }^{\#}$ boleh, \#dapat sebagai bagian dari modalitas modulasi keharusan rendah yang paling dominan yaitu sebesar 15 atau $14,56 \%$.

Untuk pasangan JW-JK dapat dijelaskan secara terperinci bahwa jenis modalitas modalisasinya sebesar 14 atau
$13,59 \%$ dengan pengungkap atau realisasi modalitas ^akan, ^bertekad, ^mungkin, insya Allah sebagai bagian dari modalitas modalisasi kemungkinan menengah yang paling dominan sebesar 7 atau $6,80 \%$. Jenis modalitas modulasinya sebesar 46 atau 44,66\% dengan pengungkap atau realisasi modalitas *harus, *wajib, *perlu, *mesti sebagai bagian dari modalitas modulasi keharusan tinggi yang paling dominan yaitu sebesar 22 atau $21,36 \%$.

\section{JENIS MODALITAS TEKS DEBAT KETIGA}

Berdasarkan jenis modalitas teks debat ketiga menunjukkan bahwa jenis modalitas teks debat ketiga yang paling dominan digunakan adalah jenis modalitas modulasi (modulation) yang menggunakan pengungkap atau realisasi modalitas sebesar 109 atau 73,15\% dibanding jenis modalitas modalisasi (modalization) yang menggunakan pengungkap atau realisasi modalitas sebesar 40 atau 26,85\%.

Bahwa data di atas juga menunjukkan bahwa teks debat ketiga menggunakan pengungkap atau realisasi modalitas *harus, *wajib, *perlu, *mesti yang merupakan bagian dari modalitas modulasi keharusan tinggi sebagai pengungkap atau realisasi modalitas yang paling dominan yaitu sebesar 49 atau 32,89\% dibanding 
pengungkap modalitas lainnya. Pengungkap atau realisasi modalitas " barangkali, $\quad{ }^{\#}$ kadang-kadang, dan *ditetapkan tidak ditemukan sama sekali pada teks tersebut.

Secara terperinci dari tabel di atas dapat dijelaskan bahwa jenis modalitas modalisasi untuk pasangan PS-HR sebesar 21 atau 14,09\% dengan pengungkap atau realisasi modalitas ^akan, ^bertekad, 'mungkin, insya Allah sebagai bagian dari modalitas modalisasi kemungkinan menengah yang paling dominan sebesar 17 atau $11,41 \%$. Jenis modalitas modulasinya sebesar 43 atau 28,86\% dengan pengungkap atau realisasi modalitas *harus, *wajib, *perlu, *mesti sebagai bagian dari modalitas modulasi keharusan tinggi yang paling dominan yaitu sebesar 20 atau $13,42 \%$.

Untuk pasangan JW-JK dapat dijelaskan secara terperinci bahwa jenis modalitas modalisasinya sebesar 19 atau 12,75\% dengan pengungkap atau realisasi modalitas ^akan, ^bertekad, ^mungkin, insya Allah sebagai bagian dari modalitas modalisasi kemungkinan menengah yang paling dominan sebesar 14 atau 9,40\%. Jenis modalitas modulasinya sebesar 66 atau 44,30\% dengan pengungkap atau realisasi modalitas *harus, *wajib, *perlu, *mesti sebagai bagian dari modalitas modulasi keharusan tinggi yang paling dominan yaitu sebesar 29 atau 19,46\%.

\section{JENIS MODALITAS TEKS DEBAT KEEMPAT}

Berdasarkan teks debat keempat menunjukkan bahwa jenis modalitas yang paling dominan digunakan adalah jenis modalitas modulasi (modulation) yang menggunakan pengungkap atau realisasi modalitas sebesar 86 atau $81,13 \%$ dibanding jenis modalitas modalisasi (modalization) yang menggunakan pengungkap atau realisasi modalitas sebesar 20 atau 18,87\%.

Tabel 01 di atas juga menunjukkan bahwa teks debat keempat menggunakan pengungkap atau realisasi modalitas *harus, *wajib, *perlu, *mesti yang merupakan bagian dari modalitas modulasi keharusan tinggi sebagai pengungkap atau realisasi modalitas yang paling dominan yaitu sebesar 41 atau 38,68\% dibanding pengungkap modalitas lainnya. Pengungkap atau realisasi modalitas \#barangkali, 'makin, dan *ditetapkan tidak ditemukan sama sekali pada teks tersebut.

Secara terperinci tabel di atas dapat dijelaskan bahwa jenis modalitas modalisasi untuk pasangan PS-HR sebesar 12 atau 11,32\% dengan pengungkap atau realisasi modalitas ^akan, ^bertekad, 
Mmungkin, insya Allah sebagai bagian dari modalitas modalisasi kemungkinan menengah yang paling dominan sebesar 8 atau $7,55 \%$. Jenis modalitas modulasinya sebesar 45 atau $42,45 \%$ dengan pengungkap atau realisasi modalitas *harus, *wajib, *perlu, *mesti sebagai bagian dari modalitas modulasi keharusan tinggi yang paling dominan yaitu sebesar 22 atau $20,75 \%$.

Untuk pasangan JW-JK dapat dijelaskan secara terperinci bahwa jenis modalitas modalisasinya sebesar 8 atau $7,56 \%$ dengan pengungkap atau realisasi modalitas ^akan, ^bertekad, ^mungkin, insya Allah sebagai bagian dari modalitas modalisasi kemungkinan menengah sebesar 4 atau 3,77\% dan realisasi modalitas *terus-menerus, *selalu dan *sering sebagai bagian dari modalisasi keseringan tinggi sebesar 4 atau 3,77\%. Jenis modalitas modulasinya sebesar 41 atau $38,68 \%$ dengan pengungkap atau realisasi modalitas *harus, *wajib, *perlu, *mesti sebagai bagian dari modalitas modulasi keharusan tinggi yang paling dominan yaitu sebesar 19 atau 17,92\%.

\section{JENIS MODALITAS TEKS DEBAT} KELIMA

Tabel 01 di atas menunjukkan bahwa jenis modalitas teks debat kelima yang paling dominan digunakan adalah jenis modalitas modulasi (modulation) yang menggunakan pengungkap atau realisasi modalitas sebesar 99 atau 77,95\% dibanding jenis modalitas modalisasi (modalization) yang menggunakan pengungkap atau realisasi modalitas sebesar 28 atau $22,05 \%$.

Tabel 01 di atas juga menunjukkan bahwa teks debat pertama menggunakan pengungkap atau realisasi modalita *harus, *wajib, *perlu, *mesti yang merupakan bagian dari modalitas modulasi keharusan tinggi sebagai pengungkap atau realisasi modalitas yang paling dominan yaitu sebesar 54 atau $42,52 \%$ dibanding pengungkap modalitas lainnya. Pengungkap atau realisasi modalitas "barangkali dan *ditetapkan tidak ditemukan sama sekali pada teks tersebut.

Secara terperinci tabel di atas dapat dijelaskan bahwa jenis modalitas modalisasi untuk pasangan PS-HR sebesar 15 atau $11,81 \%$ dengan pengungkap atau realisasi modalitas ^akan, hertekad, 'mungkin, insya Allah sebagai bagian dari modalitas modalisasi kemungkinan menengah yang paling dominan sebesar 10 atau 7,88\%. Jenis modalitas modulasinya sebesar 41 atau $32,28 \%$ dengan pengungkap atau realisasi modalitas *harus, *wajib, *perlu, *mesti sebagai bagian dari modalitas modulasi keharusan tinggi yang paling dominan 
yaitu sebesar 25 atau 19,69\%.

Untuk pasangan JW-JK dapat dijelaskan secara terperinci bahwa jenis modalitas modalisasinya sebesar 13 atau $10,24 \%$ dengan pengungkap atau realisasi modalitas ^akan, ^bertekad, ^mungkin, insya Allah sebagai bagian dari modalitas modalisasi kemungkinan menengah yang paling dominan sebesar 8 atau $6,30 \%$. Jenis modalitas modulasinya sebesar 58 atau $45,67 \%$ dengan pengungkap atau realisasi modalitas *harus, *wajib, *perlu, *mesti sebagai bagian dari modalitas modulasi keharusan tinggi yang paling dominan yaitu sebesar 29 atau $22,83 \%$.

\section{Analisis Nilai Konteks Sosial Teks Debat} Capres-Cawapres RI dengan Frekuensi Modalitas Paling Dominan Berdasarkan

\section{Teori LFS}

Konteks sosial dalam teori LFS terdiri dari tiga unsur yaitu konteks situasi, konteks budaya dan konteks ideologi. Konteks yang paling konkret adalah konteks situasi karena konteks ini langsung berhubungan dengan teks atau bahasa. Dengan kata lain, konteks situasi adalah konteks sosial kepada bahasa. Konteks yang sangat abstrak adalah konteks ideologi karena unsur ini paling jauh dari teks. Antara konteks situasi dan konteks ideologi terdapat konteks budaya. Jadi,
Lebih jelasnya untuk analisis pesan nilainilai dari segi konteks sosial pemakaian bahasa pada teks debat Capres-Cawapres RI dengan frekuensi modalitas paling dominan dari tingkat tinggi, menengah dan rendah sebagai berikut: contoh teks debat pertama dengan modalitas berupa modulasi keharusan tingkat tinggi sebagai berikut. PS (berkata): [1] Demokrasi *harus dipertahankan, dikembangkan, bagian dari cita-cita pendiri bangsa.

*Harus: Modulasi/Keharusan/Tinggi.

\section{Konteks situasi \\ a. Isi}

Arena teks ini adalah suatu ruangan tempat ajang debat berlangsung yang diselenggarakan oleh Komisi Pemilihan Umum (KPU) pada Senin malam tanggal 9 Juni 2014 yang disaksikan oleh para audiens, tema dan aturan debat dikontrol oleh seorang moderator netral tentang visi misi Capres-Cawapres terkait dengan "Pemerintahan Bersih Antikorupsi" yang ditetapkan oleh KPU serta acara debat tersebut disiarkan langsung melalui stasiun TV swasta sehingga dinikmati oleh publik masyarakat Indonesia.

b. Pelibat

Pelibat teks ini antara lain: PS selaku Capres No. Urut 1 beserta pasangan Cawapresnya HR, JW selaku Capres No. Urut 2 dan pasangan Cawapresnya JK, Dr. 
Zainal Arifin Mochtar alias ZAM, salah satu doktor UGM di bidang antikorupsi selaku moderator, para anggota KPU serta para audiens (tamu undangan) di tempat ajang perdebatan. Terdapat hubungan formalitas dengan kontinum tingkat tinggi antar para pelibat dalam ajang debat ini. Hal ini berakibat dari wacana yang disampaikan oleh peserta debat bersifat legal formal dan terikat oleh aturan-aturan ketat.

c. Cara/mode

Keterencanaan dari ajang debat ini sangatlah dipersiapkan begitu matang oleh pihak-pihak yang terlibat khususnya PS. Hal ini bisa dilihat dari diksi (pilihan) kata serta struktur bangunan kalimat dari teks [1] "Demokrasi * $\underline{\text { harus }}$ dipertahankan, dikembangkan, bagian dari cita-cita pendiri bangsa" yang disampaikan oleh PS. Proposisi kalimat tersebut sangatlah terstruktur rapi serta diujarkan dengan intonasi nada tuturan yang penuh semangat dan bergairah.

\section{Konteks budaya}

Teks yang dilontarkan oleh PS ini bersifat argumentatif. Bunyi struktur teks [1] "Demokrasi * $\underline{\text { harus }}$ dipertahankan, dikembangkan, bagian dari cita-cita pendiri bangsa" ini bersifat reiterasi dimana penutur teks membuat sebuah simpulan hujah serta penekanan implikasi yang sangat tinggi serta bertujuan untuk mempengaruhi para audiens. Hal ini bisa dianalisis dari kata demokrasi yang dipilih pembicara sebagai sebuah subjek sekaligus sebagai tema besarnya kemudian predikatnya adalah kata dipertahankan dan dikembangkan serta ditambah lagi dengan adanya stressing atau penekanan kalimat berupa modalitas harus dengan tingkat keharusan tinggi serta pemilihan bentuk kalimat pasif.

\section{Konteks ideologi}

Dalam teks kalimat: [1] "Demokrasi * dipertahankan, dikembangkan, bagian dari cita-cita pendiri bangsa" yang dituturkan oleh PS di atas penuh dengan penekanan (stressing) jika dilihat dari sisi struktur kalimatnya maupun dari intonasi nada dalam penuturan teks tersebut. Nilai ideologi utama yang diangkat oleh PS dari teks tersebut adalah indikasi dari jiwa seorang pemimpin dengan sosok yang berani dan tegas serta idealisme tingkat tinggi dalam penegakkan demokrasi sebagai warisan dari para pendiri bangsa ini. Pembicara memiliki jiwa patriot yang sangat tinggi serta pandangan hidup yang moderat. Pembicara sangat menyadari bahwa masyarakat Indonesia adalah masyarakat yang bhineka serta plural dari banyak aspek baik suku bangsa, agama, ras maupun golongan. Untuk menyatukan masyarakat yang bhineka dan plural ini 
haruslah diwadahi oleh sebuah negara yang menganut sistem pemerintahan yang bercorak demokrasi atau lebih tepatnya demokrasi Pancasila, bukan monarki dan tidak pula teokrasi.

\section{SIMPULAN}

Berdasarkan hasil analisis pada penelitian ini, simpulan yang berkaitan dengan "Kajian Modalitas LFS pada Teks Debat Kandidat Visi Misi CapresCawapres Pilpres Republik Indonesia 2014 -2019 serta Relevansinya dengan Pembelajaran Wacana di Sekolah" dikemukakan sebagai berikut:

1. Berdasarkan hasil analisis kelima teks debat visi misi capres cawapres Pemilihan Presiden 2014-2019, ditemukan bahwa dalam teks tersebut terdapat 1.150 klausa yang terdiri atas 563 klausa untuk pasangan PS-HR dan 587 klausa untuk pasangan JW-JK. Dari sejumlah klausa tersebut terkandung jumlah modalitas sebesar 562 kata dengan perincian realisasi modalitas jenis modulasi (modulation) sebesar 428 atau $76,16 \%$, sedangkan jenis modalisasi (modalization) sebesar 134 atau $23,84 \%$. Secara mendetail didapatkan bahwa pada teks debat pertama menggunakan pengungkap atau realisasi modalitas yang paling rendah yaitu sebesar 77 atau 13,71\%. Teks debat kedua menggunakan pengungkap modalitas sebanyak 103 atau 18,33\%. Teks debat ketiga menggunakan pengungkap modalitas yang paling dominan yaitu sebesar 149 atau 26,51\%. Teks debat keempat menggunakan pengungkap modalitas sebanyak 106 atau $18,86 \%$ dan teks debat kelima menggunakan pengungkap modalitas sebesar 127 atau 22,59\%. Penggunaan jenis realisasi modalitas yang paling dominan digunakan pada kelima teks debat tersebut adalah realisasi modalitas kategori *harus, *wajib, *perlu, *mesti yang termasuk ke dalam modalitas jenis modulasi keharusan tinggi yaitu sebesar 218 atau 38,79\% dibanding dengan pengungkap atau realisasi modalitas lainnya. Realisasi modalitas yang paling rendah jumlah kemunculannya yaitu makin yang masuk dalam kategori modalitas jenis modalisasi keseringan menengah dan ${ }^{*}$ kadang-kadang yang termasuk modalitas jenis modalisasi keseringan rendah dengan masingmasingnya sebesar 1 atau $0,18 \%$. Sedangkan pengungkap modalitas atau realisasi modalitas seperti ${ }^{\#}$ barangkali sebagai modalitas jenis modulasi kemungkinan rendah dan *ditetapkan sebagai bentuk modalitas jenis modulasi kecenderungan tinggi tidak ditemukan sama sekali dalam kelima teks debat 
tersebut.

2. Berdasarkan hasil analisis teks debat tersebut, ditemukan bahwa frekuensi kemunculan modalitas yang paling tinggi untuk pasangan PS-HR terdapat pada teks debat ke (III) yaitu sebesar $52,90 \%$. Berikutnya pada teks debat ke (IV) yaitu sebesar 51,35\%. Kemudian diikuti oleh teks debat ke (II) yaitu sebesar $43,88 \%$. Selanjutnya pada teks debat ke (I) yaitu sebesar 43,15\% dan tingkat keseringan kemunculan modalitas yang paling rendah terdapat pada teks debat ke (V) yaitu sebesar 40,58\%. Sedangkan untuk pasangan JW-JK frekuensi kemunculan modalitas yang paling tinggi untuk terdapat pada teks debat ke (III) yaitu sebesar $63,91 \%$. Berikutnya pada teks debat ke (II) yaitu sebesar 61,22\%. Kemudian diikuti oleh teks debat ke (V) yaitu sebesar 47,97\%. Selanjutnya pada teks debat ke (IV) yaitu sebesar 42,24\% dan tingkat keseringan kemunculan modalitas yang paling rendah terdapat pada teks debat ke (I) yaitu sebesar 39,13\%. Jika kelima teks debat tersebut diakumulasikan, maka dapat dikomparasikan bahwa frekuensi kemunculan modalitas dari keseluruhan sesi debat untuk pasangan PS-HR dari debat yang pertama hingga kelima sebesar 46,36\%, sedangkan untuk pasangan JW-JK sebesar 51,28\%.

3. Berdasarkan hasil analisis nilai konteks sosial pemakaian bahasa pada teks debat Capres-Cawapres tersebut ditemukan bahwa kedua pasangan Capres-Cawapres baik PS-HR maupun JW-JK menggunakan modalitas modulasi berupa keharusan tingkat tinggi yang paling dominan. Hal ini mengindikasikan bahwa kedua pasangan Capres-Cawapres tersebut menggunakan ungkapan-ungkapan yang penuh dengan ketegasan yang bertujuan untuk meyakinkan dan menarik simpati para audiens dalam pemaparan program-program yang hendak dilaksanakan jika mereka terpilih.

4. Temuan penelitian ini telah menunjukkan bahwa wacana visi misi capres-cawapres berdasarkan analisis modalitas teks debat yang ditawarkan oleh pasangan JW-JK lebih besar daripada pasangan PS-HR. Hal ini pun bedampak dengan kemenangan yang diraih oleh pasangan JW-JK pada pesta demokrasi Pilpres RI 2014-2019. Tentu saja dari wacana visi misi caprescawapres ini semakin memperkaya khasanah pembelajaran wacana pesta demokrasi di Indonesia pada umumnya dan pembelajaran wacana di sekolah pada khususnya. 


\section{UCAPAN TERIMAKASIH}

Penulis mengucapkan terima kasih kepada

Mitra Bestari atas masukan-masukan yang telah diberikan untuk perbaikan substansi artikel saya ini

\section{DAFTAR PUSTAKA}

Alwi, Hasan 1992, Modalitas dalam Bahasa Indonesia. Yogyakarta: Kanisisus.

Alwi, H, Dardjowidjojo, S, Lapolliwa, H. dan Moeliono, A.M. 2000. Tata Bahasa Baku Bahasa Indonesia. Jakarta: Balai Pustaka.

Asrori, Muhammad. 2007. Psikologi Pembelajaran. Bandung: CV Wacana Prima.

Bloor, T. dan M. Bloor.1995. The Functional Analysis of English. New York

Barker, Chris, 2005. Cultural Studies Teori dan Praktik. Yogyakarta: PT. Bentang Pustaka.

Badan Pembinaan dan Pengembangan Bahasa, 2011. Kamus Bahasa Indonesia. Jakarta: Badan Bahasa dan Pengembangan Bahasa Kemendikbud, Edisi Pertama.

Chaer, Abdul, 1994. Lingiustik Umum. Jakarta: Rineka Cipta.

Djajasudarma, T. Fatimah, 1993. Metode Linguistik Ancangan Metode Penelitian dan Kajian. Bandung: Eresco.

Eggins, S., 1994. An Introduction to Sistemic Functional Linguistik. London: Pinter.

Eriyanto, 2013. Analisis Naratif (Dasar-dasar dan Penerapannya dalam Analisis Teks Berita Media). Jakarta: Kencana Prenada Media Group.

Endraswara, Suwardi, 2013. Filsafat Ilmu (Konsep,Sejarah,dan Pengembangan Metode Ilmiah). Yogyakarta: CAPS.

Halliday, M.A.K, 1985. An Introduction to Functional Grammar, London: Edward Arnold.

Halliday dan R. Hasan.(Terjemah: Barori), 1992. Bahasa, Konteks dan Teks: AspekAspek Bahasa dalam Pandangan Semiotik Sosial. Yogyakarta:Gadjah Mada Universitas Prees.

Halim, Amran 1970. Bahasa dan Politik Nasional. Jakarta: Departemen
Pendidikan dan Kebudayaan.

Hoye, Leo. 1997. Adverb and Modality in English. London: Logman

Kridalaksana, Harimurti. 1993. Kamus Linguistik. Jakarta: PT Gramedia.

Lubis, A. Hamid Hasan, 1993. Analisis Wacana Pragmatik. Bandung: Angkasa

Lycan, William G. 1994. Studies in Linguistik and Philosophy. Netherlands: Kluwer Academic Publisher.

Matthiessen, $\quad$ Christian, 1992. Lexicogrammatical Cartography English System. Sydney: University of Sydney.

Palmer, F. R, 1979. Modality and The English

Modals. London: Long Man Group Limited. 1986. Mood and Modality. Malta: Cambridge University Press.

Ramlan, M., 2001. Sintaksis Ilmu Bahasa Indonesia. Yogyakarta: CV Karyono.

Samsuri. 1994. A nalisis Bahasa. Jakarta:

Erlangga.

Saragih, A., 2001. Bahasa dalam Konteks Sosial: Pendekatan Linguistik Fungsional Sistemik terhadap Tata Bahasa dan Wacana. Medan: Program Pascasarjana USU. 2006. Teks dan Konteks Wacana. Penerbit: Universitas Sumatra Utara

Sudaryanto, 1998. Metode Linguistik: Ke Arah Memahami Metode Linguistik. Yogyakarta: Gajah Mada University Press.

Sobur, Alex, 2012. Analisis Teks Media (Suatu Pengantar Untuk Analisis Wacana, Analisis Semiotik dan Analisis Freming). Bandung: PT Remaja Rosdakarya.

Schiffrin, Deborah, 2007. Ancangan Kajian

Wacana. Yogyakarta: Pustaka Pelajar.

Tim Pustaka Phoenix, 2012. Kamus Umum Bahasa Indonesia. Jakarta: PT Media Pustaka Phoenik. , 1987. Pengajaran

Wacana. Bandung: PT. Angkasa.

Thomson, Geoff. 1991. Introducing Functional Grammar. Cina: Edwad Arnold (Publishers) Ltd.

Wren, P.C. dan Maritin, H.1990. Highschool English Grammar And Composition . New Delhi: S. Chand \& Company (Pyt) Ltd. 